\title{
Nitrogen application save phosphorus deficiency in maize inbred line QXH0121
}

\author{
Bingying Leng ${ }^{2}$, Hanhan Zhang ${ }^{1,2}$, Ming $\mathrm{Li}^{2,3}$, Chunhua $\mathrm{Mu}^{2}$, Enying Zhang ${ }^{1 *}$ and Xia Liu ${ }^{2,3^{*}}$ \\ ${ }^{1}$ Agricultural College, Qingdao Agricultural University, Qingdao, Shandong, 266109, China \\ ${ }^{2}$ Maize Research Institute, Shandong Academy of Agricultural Sciences, Jinan, Shandong, 250100, China \\ ${ }^{3}$ College of Life Sciences, Shandong Normal University, Jinan, Shandong, China
}

\begin{abstract}
Nitrogen and phosphorus dual stress significantly inhibited the maize growth and decreased the accumulation of nitrogen and phosphorus in plants. The co-application of nitrogen and phosphorus most significantly increased the biomass compared to the dual deficiency stress, and to our surprise, the repair effect of nitrogen application alone was basically similar to the repair effect of simultaneous application of nitrogen and phosphorus reflected in biomass as well as nitrogen and phosphorus content. Transcriptomic analysis showed that DEGs related to phosphorus transporters in N versus NP group and N versus $\mathrm{P}$ group were all up-regulated. These all confirm that the nitrogen application alone mitigated damages caused by low nitrogen and phosphorus dual stress comparable to that of nitrogen and phosphorus co-application. These indicate that the presence of nitrogen is conducive to the accumulation and transportation of phosphorus.
\end{abstract}

\section{Introduction}

Nitrogen and phosphorus are indispensable macroelements for plant growth and development. Nitrogen is the constituent of all amino acids and proteins and is the main component of nucleotides, chlorophyll and so on other main molecules in the cell [1-3]. Phosphorus is the components of nucleic acids, phospholipids, adenosine phosphate, various enzymes amongst other molecules, and it is involved in photosynthesis, respiration, energy storage and transfer and other important processes [4-6].

The form of phosphorus absorbed by plants is mainly inorganic phosphorus $\left(\mathrm{HPO}_{3}{ }^{-}\right.$, or $\left.\mathrm{Pi}\right)$, and nitrate $\left(\mathrm{NO}_{3}{ }^{-}\right)$ is the main source of nitrogen for most plants [7, 8]. At present, most soils are deficient in Pi and it was reported that there are currently 5.7 billion hectares of $\mathrm{Pi}$ deficiency lands in the world now [9, 10]. Studies showed that small changes in parameters related to root growth have a great effect on phosphorus absorption. Severe Pi deficiency limits total plant growth and yield, including root growth $[11,12]$. Nitrogen deficiency significantly decreases plant biomass, leaf chlorophyll content, leaf area and photosynthetic rate in most plant species [13, 14]. Application of nitrogen and phosphorus fertilizer is a general strategy to improve crop yield [15, 16]. The absorption and utilization of different elements by plants often have interaction, nitrogen and phosphorus maybe the same [17]. The absorption and utilization of different elements by plants often encounter element to element interactions, and nitrogen and phosphorus interaction is a nice example [17].
Recent studies reported the phosphorus and nitrogen signaling interaction in Arabidopsis. PHOSPHATE2 (PHO2) and NITRATE TRANSPORTER1.1 (NRT1.1) affect each other's transcript level and the accumulation of PHOSPHATE STARVATION RESPONSE1 (PHR1), and this process depends on $\mathrm{NO}^{-}$uptake signaling mediated by NRT1 [18]. In Arabidopsis, NITROGEN LIMITATION ADAPTATION (NLA) and PHO2 regulate the degradation of PHOSPHATE TRANSPORTER1 (PHT1) protein in different growth periods [19]. A recent study in rice showed that nitrate can activate both phosphate and nitrate utilization in rice. Nitrate sensor NRT1.1B can regulate phosphorus signalling networks by promoting the ubiquitination and degradation of phosphate signalling repressor SPX4, and the central transcription factor of nitrate signalling NPL3 was controlled by SPX4 [20]. In Arabidopsis, the NLA regulated by low phosphate induced miR827 and miR399 maintain phosphate balance by acting directly or indirectly on PHF1 and PHT1.1 [21]

Maize, as an important food, feed and bio-energy crop, is of great significance not only to agriculture but also to the development of animal husbandry [22]. Many studies on molecular mechanism of nitrogen and phosphorus interaction were carried out in Arabidopsis thaliana and rice, but there was few in maize. Nitrogen and phosphorus are vital macroelements for maize growth. Then, when undergone low nitrogen and phosphorus dual deficiency, what is the difference between nitrogen and phosphorus co-application and nitrogen or phosphorus application alone on plant growth and the processes of nitrogen, phosphorus, and

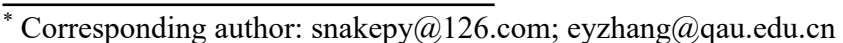


potassium accumulation and transportation? What kind of interaction exists between nitrogen and phosphorus? This paper discusses these issues at the physiological and transcriptional levels.

\section{Materials and methods}

\section{1. plant materials and culture condition}

In this study, QXH0121, a low phosphorus sensitive maize genotype stored in our laboratory was selected [23]. The seeds were disinfected and washed according to [24], and germinated on sterilized filter paper for three days. Then seedlings were transplanted into plastic plots (9 $\mathrm{cm} \times 21 \mathrm{~cm} \times 18 \mathrm{~cm}$, three seedlings in each plot) filled with quartz sand and cultivated in controlled chamber with a relative humidity of $60 \%-70 \%$, a temperature of $28 \pm 3^{\circ} \mathrm{C}$ and a light cycle of $16 / 8$ hours (day/night). Afterwards, seedlings were irrigated with Hoagland's nutrient solution with a $\mathrm{pH}$ of 6 every 2-3 days until they reached the three fully expanded leaf stage.

Low nitrogen and low phosphorus stress treatment (2 $\mathrm{mM} \mathrm{CaCl}{ }_{2}$ instead of $\mathrm{Ca}\left(\mathrm{NO}_{3}\right)_{2} \cdot 4 \mathrm{H}_{2} \mathrm{O}$, without $1.25 \mathrm{mM}$ $\mathrm{NH}_{4} \mathrm{NO}_{3}$, and $0.5 \mathrm{mM} \mathrm{KCl}$ instead of $\mathrm{KH}_{2} \mathrm{PO}_{4}$ ) were done for 10 days when seedlings grown to the stage with three fully expanded leaves. In order to study the interaction of nitrogen and phosphorus under low phosphorus stress, different concentrations of nitrogen and phosphorus were added to the nutrient solution. The Control group was continuously treated with low phosphorus and nitrogen. $\mathrm{N}$ group added $5 \mathrm{mM} \mathrm{NH}_{4} \mathrm{NO}_{3}$.

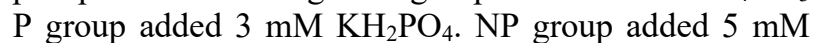
$\mathrm{NH}_{4} \mathrm{NO}_{3}$ and $3 \mathrm{mM} \mathrm{KH} \mathrm{PO}_{4}$. The Normal group which played a comparative role was irrigated with Hoagland's nutrient solution without low nitrogen and phosphorus stress. At least five biological replicates (15-20 plants for each treatment group) were done for each treatment and used for all measurements.

\subsection{Determination of plant growth parameter}

After 10 days of treatments, the plant height and primary root length were measured by ruler. Rinsed roots were scanned with an Epson transparency unit (Epson, Beijing, China) and root volume, surface area and mean diameter were calculated. Plants were rinsed and wiped with absorbent paper and cut into shoots and roots, and the fresh weight (FW) and dry weight (DW) of shoots and roots was measured. Five biological replicates were applied for all parameters.

\subsection{Total nitrogen, phosphorus and $\mathrm{K}^{+}$content}

The roots and shoots dried to constant weight were used to determine nitrogen content, phosphorus and $\mathrm{K}^{+}$ content. The nitrogen content was measured by Kjehldahl method. The total phosphorus content in roots and shoots were measured in accordance with previous published protocols [23] and the $\mathrm{K}^{+}$content was determined with a flame photometer (Flame Photometer 410, Sherwood).

\subsection{RNA extraction and transcriptomic data analyses}

Seedlings undergone N, P and NP treatment for 10 days were rinsed and the tender part of roots were cut and put into liquid nitrogen and ground up. RNA was extracted by using TRIzol (Invitrogen, USA) and purified using the RNA easy Mini RNA kit (Qiagen, Shanghai, China). The mRNA was enriched using magnetic beads with Oligo (dT) by complementation of A-T with ployA tail of mRNA. Then mRNA was broken and used to synthesize the two-strand cDNA in order to build cDNA libraries. Finally, high throughput sequencing via an Illumina High-Seq2000 sequencing system (Novogene Co., Ltd., Beijing, China) was carried out with the constructed cDNA library.

HISAT software was selected to localize the filtered clean reads with the maize B73 RefGen V4 genomic DNA sequence. And BLAST (2.2.23) analysis was used to annotate known genes (http://blast.ncbi.nlm.nih.gov/Blast.cgi). Gene expression was calculated by a fragment per kilobase of exon model per million mapped reads (FPKM). And genes with parameters of $\mid \log _{2}$ (fold change) $\mid>1.5$ and $\mathrm{P}<0.05$ were identified as differentially expressed genes (DEs). And Gene Ontology (GO) enrichment analysis via GO-seq and Kyoto Encyclopedia of Genes and Genomes (KEGG) pathway analysis were also performed.

\section{5. $\mathrm{qRT}-\mathrm{PCR}$ validation}

The total RNA of the roots treated with nitrogen, phosphorus and co-nitrogen and phosphorus for 10 days were extracted using an E.Z.N.A. Plant RNA Kit (Omega Bio-tek, USA). PrimeScript ${ }^{\mathrm{TM}}$ RT reagent Kit (Takara) was used to obtain cDNA. qRT-PCR was carried out in a fluorometric thermal cycler (Bio-Rad CFX96 ${ }^{\mathrm{TM}}$ Real-time PCR System) using SYBR Premix Ex TaqTM (TaKaRa) as the instructions described. The $2^{-\Delta \Delta \mathrm{Ct}}$ method was used to calculate the relative expression value. Primers used in qRT-PCR verification showed in Table S1.

\subsection{Statistical analysis}

All statistical analyses were performed by the SPSS 16.0 (SPSS, Chicago, IL, USA). Data were analyzed by ANOVA procedure. Differences in means among treatments were compared based on Duncan's tests and considered significant at $P \leq 0.05$. 


\section{Results}

\subsection{Single nitrogen application significantly mitigated injuries caused by low phosphorus and nitrogen dual stress than phosphorus application}

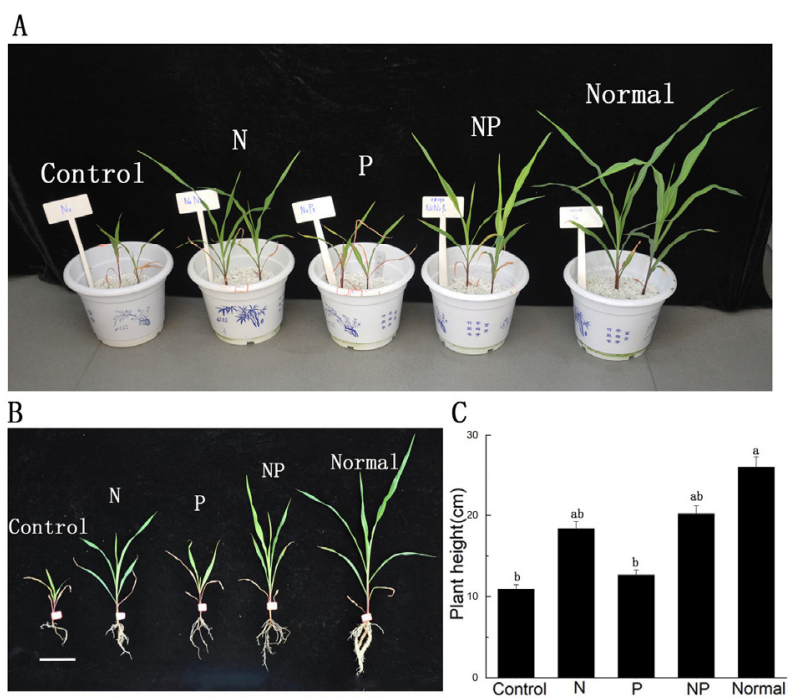

Fig. 1. Plant phenogram (A, B) and plant height above ground (B) of Control group, nitrogen application group ( $\mathrm{N}$ group), phosphorus application group ( $\mathrm{P}$ group), nitrogen and phosphorus co-application group (NP group) and Normal group of QXHO121 maize seedlings. Bar $=10 \mathrm{~cm}$. Data are average of 5 replicates $\pm \mathrm{SD}$, and different letters indicate significant difference at $\mathrm{P} \leq 0.05$.
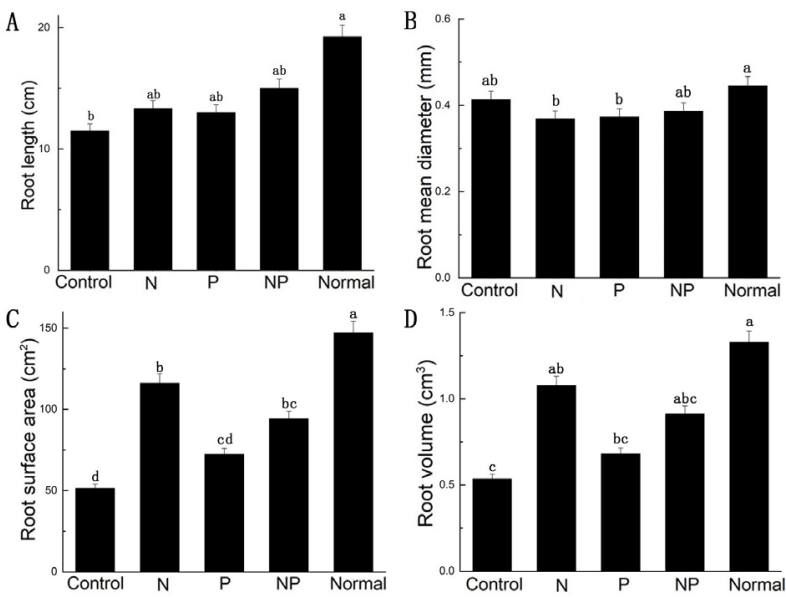

Fig. 2. Root length (A), root mean diameter (B), root surface area (C) and root volume (D) of Control group, $\mathrm{N}$ group, $\mathrm{P}$ group, NP group and Normal group of QXHO121 maize seedlings. Data are average of 5 replicates $\pm \mathrm{SD}$, and different letters indicate significant difference at $\mathrm{P} \leq 0.05$.

Under low phosphorus and nitrogen stress, plant growth and development were inhibited, leaves were yellow and withered. Regardless of whether phosphorus was applied or not, the plants with nitrogen application recovered to a certain extent and the stress symptoms alleviated. Plant growth in the $\mathrm{N}$ group was superior to that of $\mathrm{P}$ group but weaker than that of NP group (Fig. 1 A, B). The plant height of NP group was significantly longer than that of $\mathrm{P}$ group. And there was no significant difference between that of $\mathrm{N}$ group and NP group (Fig. 1 C).

Results on the roots showed that there was no obvious difference between the total root length and root mean diameter of Control, N, P and NP group. The total length of root in Normal group was significantly longer than that in other groups. The root diameter of $\mathrm{N}$ group and $\mathrm{P}$ group was markedly thinner than that of Normal group (Fig. 2 A, B). But the root surface area and root volume showed marked difference between Control, N, $\mathrm{P}, \mathrm{NP}$ and Normal group and the two indicators show similar trends. In addition to Normal group, the root surface area and root volume of $\mathrm{N}$ group were the highest, then followed by those of NP group, $\mathrm{P}$ group and those of Control group were the lowest (Fig. 2 C, D).

\subsection{Biomass analysis of maize plants under different nitrogen and phosphorus conditions}

Fig. 3 showed that compared with the Control group, the fresh weight of the shoots and roots of N and NP group was markedly higher. Moreover, the fresh weight of the shoots of NP group was a little higher than that of $\mathrm{N}$ group but significantly lower than that of Normal group. There was no significant difference between the fresh weight of roots of $\mathrm{N}$ group and NP group and both of them were a little lower than that of Normal group. Surprisingly, there was no significant difference between the shoots and roots fresh weight of $\mathrm{P}$ group and Control group (Fig. 3 A). The dry weight of shoots and roots was similar to that of the fresh weight (Fig. 3 B). Fig. $3 \mathrm{C}$ showed that the root/shoot ratio of Control group was the highest, and that of Normal group was the lowest. P group was second only to that of Control group. There was no significant difference between $\mathrm{N}$ group and $\mathrm{NP}$ group (Fig. $3 \mathrm{C}$ ).

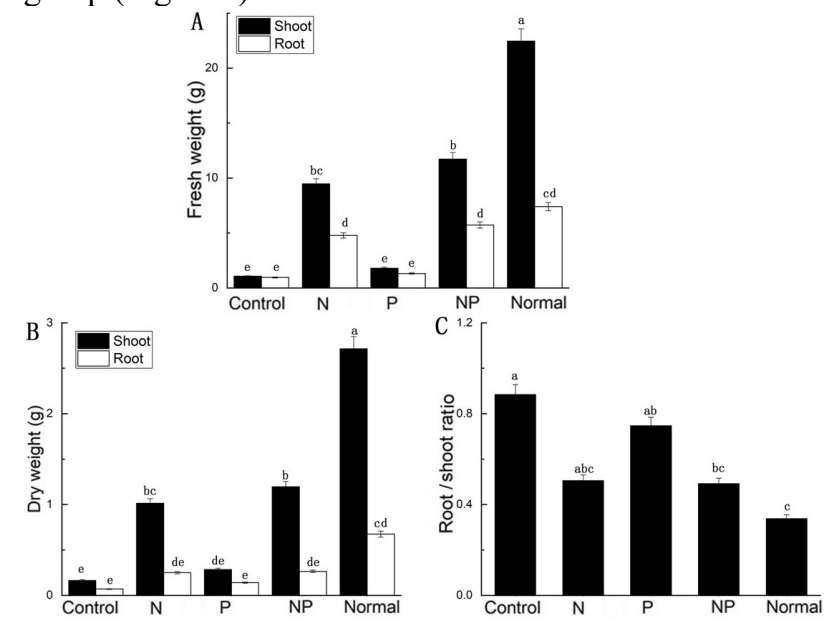

Fig. 3. Fresh weight (A) and dry weight (B) of shoots and roots and root/shoot ratio of Control group, $\mathrm{N}$ group, $\mathrm{P}$ group, NP group and Normal group of QXHO121 maize seedlings. Data are average of 5 replicates $\pm \mathrm{SD}$, and different letters indicate significant difference at $\mathrm{P} \leq 0.05$. 


\subsection{The determination of nitrogen, phosphorus and $\mathrm{K}^{+}$content in whole plant}

To further investigate the distribution of nitrogen, phosphorus and $\mathrm{K}^{+}$distribution, the nitrogen, phosphorus and $\mathrm{K}^{+}$content in shoots and roots of different groups were determined. Fig. 4 A showed that the shoot nitrogen content of NP group was the highest and followed by Normal group and $\mathrm{N}$ group, and there was no significant difference between Control group and that of $\mathrm{P}$ group. The root nitrogen content showed different trends. The root nitrogen content of Normal group was the highest, and was a little higher than that of NP group and followed by $\mathrm{N}$ group. The root nitrogen content of $\mathrm{N}$ group was significantly higher than that of Control group, and there was no significant difference between Control group and that of P group. Nitrogen and phosphorus coapplication even made the nitrogen content per unit dry weight of the plant equal to that of the Normal group plant. However, the application of phosphorus had little effect on the nitrogen accumulation of plants undergone nitrogen and phosphorus dual starvation.
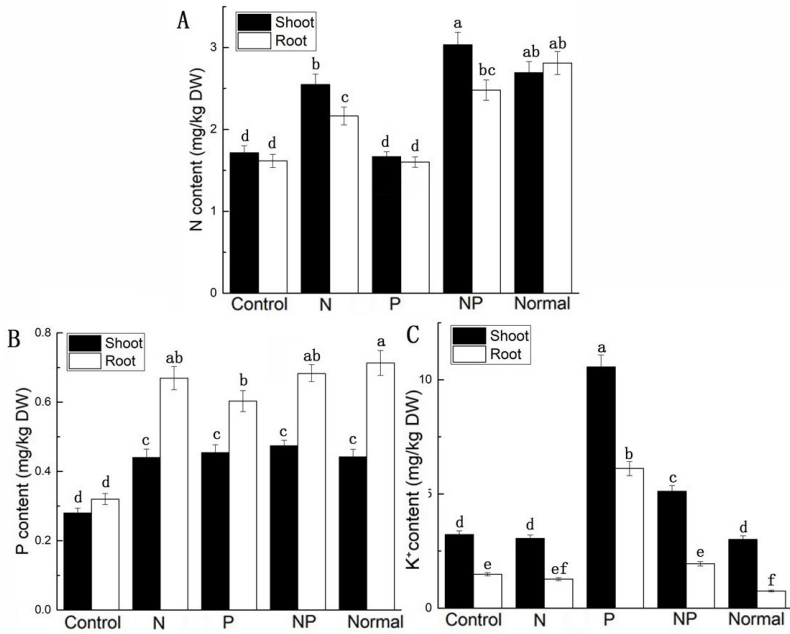

Fig. 4 Shoot and root total N, P content and $\mathrm{K}^{+}$content of Control group, $\mathrm{N}$ group, $\mathrm{P}$ group, $\mathrm{NP}$ group and Normal group of QXHO121 maize seedlings. Data are average of 5 replicates $\pm \mathrm{SD}$, and different letters indicate significant difference at $\mathrm{P} \leq$ 0.05 .

The phosphorus content in shoots of Normal group, $\mathrm{N}$ group, NP group and $\mathrm{P}$ group showed no marked difference, and that of Control was significantly lower than them. The phosphorus content in roots of Normal group, $\mathrm{N}$ group and NP group showed no marked difference, and that of $\mathrm{P}$ group was lower than them, and that of Control was the lowest (Fig. 4 B). The application of nitrogen or phosphorus or both all played a significant role in promoting the phosphorus content per unit dry weight. The comparison results in Fig. 4 A and B showed that the application of nitrogen can significantly promote the accumulation of phosphorus, but the application of phosphorus has no significant effect on the accumulation of nitrogen.

The $\mathrm{K}^{+}$content in shoots of $\mathrm{P}$ group was significantly higher than that of other groups, and there was no significant difference between Normal group, $\mathrm{N}$ group and Control group. The $\mathrm{K}^{+}$content in roots of $\mathrm{P}$ group was strikingly higher than that of other groups, too. Then followed by that of NP group. And there was no significant difference between that of Control and NP group. The $\mathrm{K}^{+}$content in roots of Normal group was the lowest (Fig. 4 C). The high levels of $\mathrm{K}^{+}$content in $\mathrm{P}$ group and NP group maybe due to the increased $\mathrm{K}^{+}$ applied with the $\mathrm{H}_{2} \mathrm{PO}_{4}^{-}$. But the interesting thing was that when applied with both nitrogen and phosphorus, the $\mathrm{K}^{+}$content in shoots and roots both decreased significantly compared with the group applied with phosphorus alone.

\subsection{Transcriptomic analysis of nitrogen and phosphorus mediated gene expression profiles in QXH0121 corresponding to low nitrogen and phosphorus dual stress}

In order to explore the molecular reason why the recovery after nitrogen application was significantly better than that of phosphorus application, and why the most significant remission was achieved when both phosphorus and nitrogen were applied together. The transcriptome sequencing of inbred line QXH0121 plants of N, P and NP group were performed. The RNA-Seq data analysis in this study contained three RNA libraries: $\mathrm{N}$ roots, $\mathrm{P}$ roots and NP roots. Fig. 5 showed the number of differentially expressed genes (DEGs) in roots of different groups. Compared with $\mathrm{P}$ group, there were 1885 DEGs (1134 up-regulated and 751 down-regulated) in roots of $\mathrm{N}$ group. Compared with $\mathrm{NP}$ group, there were 480 DEGs (400 up-regulated and 80 downregulated) in roots of $\mathrm{N}$ group.

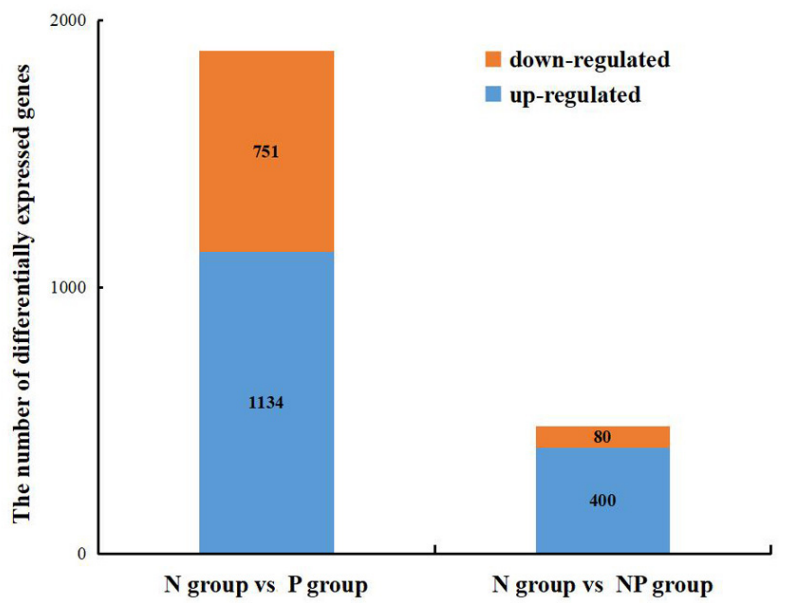

Fig. 5 Overview of differentially expressed genes (DEGs) in N group versus $\mathrm{P}$ group and $\mathrm{N}$ group versus $\mathrm{NP}$ group of QXHO121 roots. A total of 1,885 and 480 genes expressed differentially in $\mathrm{N}$ group versus $\mathrm{P}$ group and $\mathrm{N}$ group versus NP group, respectively, were identified according to the threshold that $\mid \log _{2}$ (fold change) $\mid>1.5$ and $\mathrm{P}<0.05$.

\subsection{Functional classification by $\mathrm{GO}$}

Plants absorb nutrients mainly from roots, thus the GO enrichment analysis of roots was carried out. In the three main categories (level 1) of GO analysis, DEGs between $\mathrm{N}$ group and $\mathrm{P}$ group mainly involved in 12 level-2 GO terms under biological process in which most of the 
genes involved in single-organism process, 1 level-2 GO terms under cellular component and 17 level-2 GO terms under molecular function in which most of the genes were related to catalytic activity (Fig. 6 A). Most of the DEGs between $\mathrm{N}$ group and NP group were related to molecular function (mainly involved in 12 level-2 GO terms and most of these were related to hydrolase activity and oxidoreductase activity), then followed by biological process (mainly involved in 8 level-2 GO terms). DEGs related to cellular component mainly involved in 10 level-2 GO terms (Fig. 6 B).

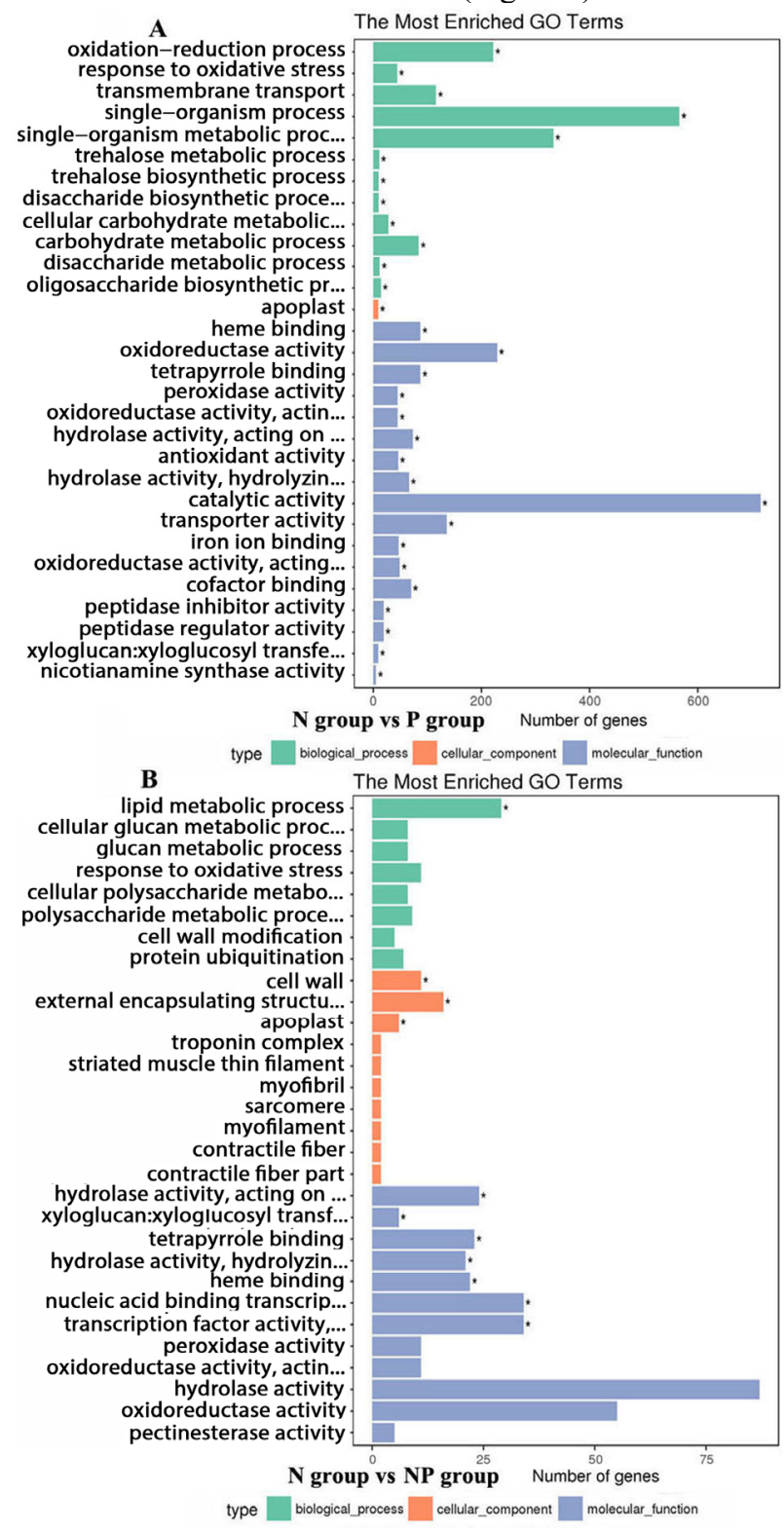

Fig. 6. Gene Ontology (GO) analysis of DEGs in roots of $N$ group versus $\mathrm{P}$ group (A) and $\mathrm{N}$ group versus NP group (B) in cellular components, molecular functions and biological processes.

\subsection{Functional classification by KEGG}

KEGG analysis revealed that most of the DEGs between $\mathrm{N}$ group and $\mathrm{P}$ group mapped to metabolic pathway, biosynthesis of secondary metabolites pathway and phenylpropanoid biosynthesis, and some mapped to starch and sucrose metabolism, nitrogen metabolism, amino sugar and nucleotide sugar metabolism, flavonoid biosynthesis, glyoxylate and dicarboxylate metabolism and cyanoamino acid metabolism and so on (Fig. 7 A). The most DEGs between N and NP group mapped to metabolic pathway and biosynthesis of secondary metabolites, too. And some others mapped to plant hormone signal transduction, phenylpropanoid biosynthesis, starch and sucrose metabolism and so on (Fig. 7 B).

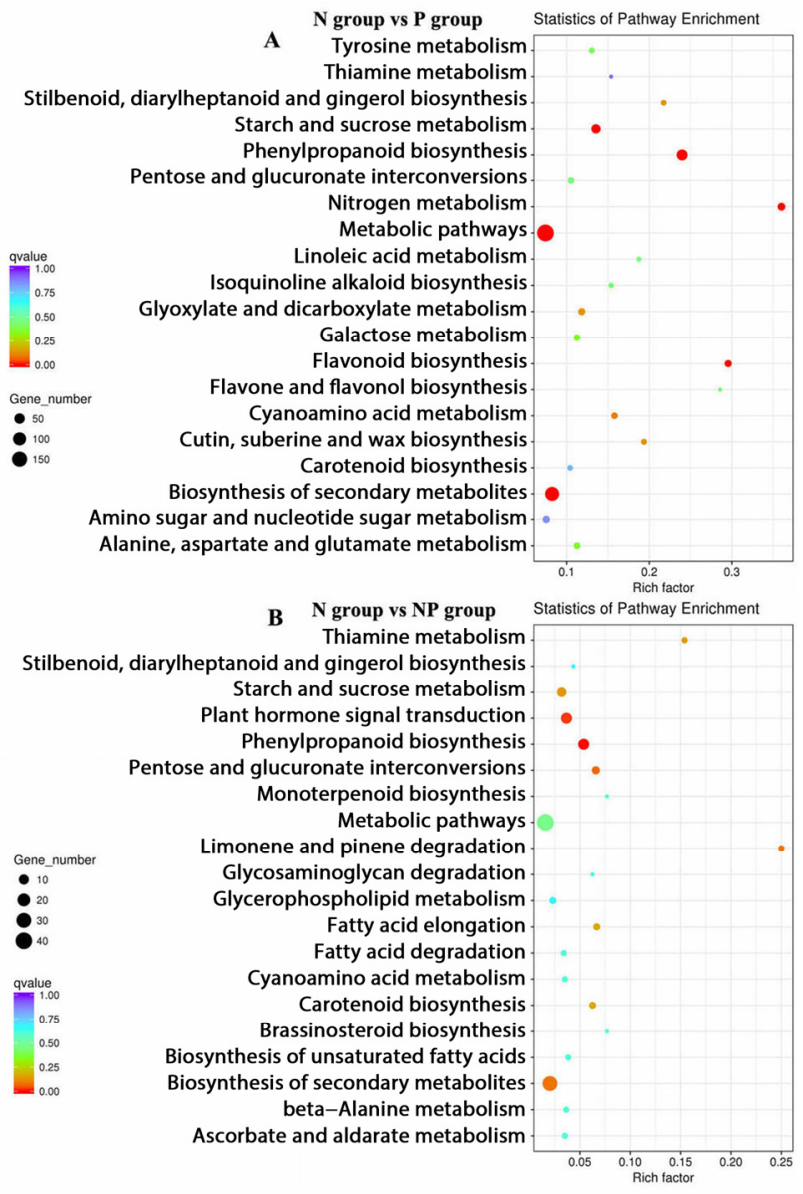

Fig. 7. Kyoto Encyclopedia of Genes and Genomes (KEGG) pathway analysis of DEGs in roots of $\mathrm{N}$ group versus $\mathrm{P}$ group

(A) and N group versus NP group (B).

\subsection{Key DEGs related to nitrogen metabolism between $\mathbf{N}$ group, $P$ group and NP group}

Transcriptome analysis revealed that there were many DEGs found in $\mathrm{N}$ group vs $\mathrm{P}$ group and a few in $\mathrm{N}$ group vs NP group involved in nitrogen metabolism (Table 1). Among the 16 DEGs of $\mathrm{N}$ group vs $\mathrm{P}$ group, 12 of the them were down-regulated. These results further indicated that nitrogen application showed evident anesis on nitrogen and phosphorus dual starvation compared with phosphorus application and as a result the expression level of nitrate transporters of $\mathrm{N}$ group needed no further improvement but those of $\mathrm{P}$ group needed. In $\mathrm{N}$ group vs NP group, there were fewer DEGs related to nitrogen compared with $\mathrm{N}$ group vs $\mathrm{P}$ group. Only 3 DEGs were found and Zm00001d026221 (NRT1/ PTR FAMILY 8.3) involved in nitrogen metabolism were 
down-regulated. The down-regulation of DEGs related to nitrogen metabolism maybe one of the most important reasons why the nitrogen content of $\mathrm{P}$ group was lower than that of $\mathrm{N}$ group. From the nitrogen content point of view, there was no significant difference in nitrogen accumulation between N and NP groups, so there were less DEGs related to nitrogen metabolism.

Table 1 DEGs involved in nitrogen metabolism of QXH0121 identified in $\mathrm{N}$ group versus $\mathrm{P}$ group and $\mathrm{N}$ group versus $\mathrm{NP}$ group by transcriptomic analysis $\left(\mid \log _{2}\right.$ FoldChange $\mid>1.5$, and Pval $<0.05)$.

\begin{tabular}{|c|c|c|c|c|}
\hline $\begin{array}{l}\text { Treat- } \\
\text { ment }\end{array}$ & Gene_ID & $\begin{array}{l}\log _{2} \text { FoldCh } \\
\text { ange }\end{array}$ & Pval & SwissProt \\
\hline \multirow{16}{*}{$\mathrm{N}$ vs $\mathrm{P}$} & $\begin{array}{c}\mathrm{Zm} 00001 \mathrm{~d} \\
025984\end{array}$ & 2.4236 & 0 & $\begin{array}{c}\text { Glutamate } \\
\text { dehydrogenase } 2\end{array}$ \\
\hline & $\begin{array}{c}\mathrm{Zm} 00001 \mathrm{~d} \\
033747\end{array}$ & 2.4047 & $\begin{array}{l}2.2025 \\
\mathrm{E}-149\end{array}$ & $\begin{array}{l}\text { Glutamine synthetase } \\
\text { root isozyme } 2\end{array}$ \\
\hline & $\begin{array}{l}\mathrm{Zm} 00001 \mathrm{~d} \\
014976\end{array}$ & 1.6513 & $\begin{array}{c}1.3184 \\
\mathrm{E}-23\end{array}$ & $\begin{array}{l}\text { High-affinity nitrate } \\
\text { transporter } 2.2\end{array}$ \\
\hline & $\begin{array}{c}\mathrm{Zm} 00001 \mathrm{~d} \\
042684\end{array}$ & 2.008 & $\begin{array}{l}4.93 \mathrm{E}- \\
227\end{array}$ & $\begin{array}{l}\text { Protein NRT1/ PTR } \\
\text { FAMILY 5.10 }\end{array}$ \\
\hline & $\begin{array}{c}\mathrm{Zm} 00001 \mathrm{~d} \\
018161\end{array}$ & -1.5604 & 0 & $\begin{array}{l}\text { Ferredoxin--nitrite } \\
\text { reductase }\end{array}$ \\
\hline & $\begin{array}{l}\mathrm{Zm00001d} \\
054057\end{array}$ & -1.8156 & $\begin{array}{l}1.8324 \\
\mathrm{E}-127\end{array}$ & $\begin{array}{l}\text { High-affinity nitrate } \\
\text { transporter } 2.2\end{array}$ \\
\hline & $\begin{array}{c}\mathrm{Zm} 00001 \mathrm{~d} \\
052164\end{array}$ & -1.8915 & $\begin{array}{c}1.4803 \\
\mathrm{E}-41\end{array}$ & $\begin{array}{l}\text { Ferredoxin--nitrite } \\
\text { reductase }\end{array}$ \\
\hline & $\begin{array}{c}\mathrm{Zm} 00001 \mathrm{~d} \\
054060\end{array}$ & -1.9115 & $\begin{array}{c}8.5221 \\
\mathrm{E}-287\end{array}$ & $\begin{array}{l}\text { High-affinity nitrate } \\
\text { transporter } 2.2\end{array}$ \\
\hline & $\begin{array}{c}\mathrm{Zm} 00001 \mathrm{~d} \\
049995\end{array}$ & -1.994 & $\begin{array}{l}7.8295 \\
\text { E-206 }\end{array}$ & $\begin{array}{l}\text { Nitrate reductase } \\
{[\mathrm{NADH}] 1}\end{array}$ \\
\hline & $\begin{array}{l}\mathrm{Zm} 00001 \mathrm{~d} \\
018206\end{array}$ & -2.2683 & $\begin{array}{l}8.2927 \\
\mathrm{E}-301\end{array}$ & $\begin{array}{l}\text { Nitrate reductase } \\
{[\mathrm{NAD}(\mathrm{P}) \mathrm{H}]}\end{array}$ \\
\hline & $\begin{array}{c}\mathrm{Zm} 00001 \mathrm{~d} \\
044099\end{array}$ & -2.3309 & $\begin{array}{l}3.5322 \\
\mathrm{E}-131\end{array}$ & Carbonic anhydrase \\
\hline & $\begin{array}{c}\mathrm{Zm00001d} \\
031769\end{array}$ & -3.964 & 0 & $\begin{array}{l}\text { Nitrate reductase } \\
\quad[\text { NADH] } 1\end{array}$ \\
\hline & $\begin{array}{c}\mathrm{Zm} 00001 \mathrm{~d} \\
012138\end{array}$ & -1.5529 & $\begin{array}{c}9.41 \mathrm{E}- \\
10\end{array}$ & $\begin{array}{l}\text { Protein NRT1/ PTR } \\
\text { FAMILY } 8.1\end{array}$ \\
\hline & $\begin{array}{c}\mathrm{Zm} 00001 \mathrm{~d} \\
017666\end{array}$ & -1.5578 & 0 & $\begin{array}{l}\text { Protein NRT1/ PTR } \\
\text { FAMILY } 7.3\end{array}$ \\
\hline & $\begin{array}{c}\mathrm{Zm} 00001 \mathrm{~d} \\
014060\end{array}$ & -2.2696 & $\begin{array}{l}4.92 \mathrm{E}- \\
56\end{array}$ & $\begin{array}{l}\text { Protein NRT1/ PTR } \\
\text { FAMILY } 5.2\end{array}$ \\
\hline & $\begin{array}{l}\mathrm{Zm} 00001 \mathrm{~d} \\
-026221\end{array}$ & $\begin{array}{l}-2.6451 \\
-\quad-\quad-\end{array}$ & $\begin{array}{l}1.93 \mathrm{E}- \\
-\underline{40}-\end{array}$ & $\begin{array}{l}\text { Protein NRT1/ PTR } \\
\text { _ FAMILY } 8.3 . \underline{3}-\ldots\end{array}$ \\
\hline & $\begin{array}{c}\mathrm{Zm00001d} \\
040468\end{array}$ & 1.53 & $\begin{array}{l}2.98 \mathrm{E}- \\
23\end{array}$ & $\begin{array}{l}\text { Probable peptide/nitrate } \\
\text { transporter }\end{array}$ \\
\hline \multirow[t]{2}{*}{$\begin{array}{l}\mathrm{N} \text { vs } \\
\mathrm{NP}\end{array}$} & $\begin{array}{c}\mathrm{Zm} 00001 \mathrm{~d} \\
044640\end{array}$ & 1.6089 & $\begin{array}{c}4.03 \mathrm{E}- \\
18\end{array}$ & $\begin{array}{l}\text { Probable peptide/nitrate } \\
\text { transporter }\end{array}$ \\
\hline & $\begin{array}{c}\mathrm{Zm} 00001 \mathrm{~d} \\
026221\end{array}$ & -1.689 & $\begin{array}{c}3.88 \mathrm{E}- \\
14\end{array}$ & $\begin{array}{c}\text { Protein NRT1/ PTR } \\
\text { FAMILY } 8.3\end{array}$ \\
\hline
\end{tabular}

\subsection{Key DEGs related to Pi transporters activity between $\mathrm{N}$ group, $\mathrm{P}$ group and NP group}

Some DEGs related to $\mathrm{Pi}$ transporters of $\mathrm{N}$ group versus $\mathrm{P}$ group and $\mathrm{N}$ versus NP group were found (Table 2). And all genes in $\mathrm{N}$ group versus $\mathrm{P}$ group were upregulated trends. Among these significantly up-regulated genes, Zm00001d031875 (inorganic phosphate transporter 1-2) showed the highest expression level. There were only 3 genes DEGs related to Pi transporters in $\mathrm{N}$ versus NP group. And Zm00001d028367 (purple acid phosphatase 3), Zm00001d029038 (acid phosphatase 1) and Zm00001d031875 (inorganic phosphate transporter 1-6) were all up-regulated, too. The root phosphorus content of $\mathrm{N}$ groups was a little higher than that of $\mathrm{P}$ group, but these $\mathrm{Pi}$ related transporters still expressed upward. These all indicated that nitrogen might promote the expression of genes related to phosphorus metabolism.

Table 2 Differentially expressed transporters involved in phosphorus metabolism of QXH0121 identified in N group versus $\mathrm{P}$ group and $\mathrm{N}$ group versus $\mathrm{NP}$ group by transcriptomic analysis $\left(\mid \log _{2}\right.$ FoldChange $\mid>1.5$, and Pval $\left.<0.05\right)$.

\begin{tabular}{|c|c|c|c|c|}
\hline $\begin{array}{c}\text { Treat- } \\
\text { ment }\end{array}$ & Gene_ID & $\begin{array}{l}\log _{2} \text { Fold } \\
\text { Change }\end{array}$ & Pval & SwissProt \\
\hline \multirow{6}{*}{$\mathrm{N}$ vs $\mathrm{P}$} & $\begin{array}{c}\mathrm{Zm00001d} \\
031875\end{array}$ & 5.4812 & 0 & $\begin{array}{l}\text { Inorganic phosphate } \\
\text { transporter } 1-2\end{array}$ \\
\hline & $\begin{array}{c}\mathrm{Zm} 00001 \mathrm{~d} \\
032850\end{array}$ & 4.7683 & $\begin{array}{l}0.0009 \\
2953\end{array}$ & $\begin{array}{l}\text { Sucrose-phosphate } \\
\text { synthase }\end{array}$ \\
\hline & $\begin{array}{l}\mathrm{Zm} 00001 \mathrm{~d} \\
031875\end{array}$ & 2.8161 & $\begin{array}{l}3.94 \mathrm{E}- \\
10\end{array}$ & $\begin{array}{c}\text { Phosphate transporter } \\
\text { PHO 1-3 }\end{array}$ \\
\hline & $\begin{array}{l}\mathrm{Zm} 00001 \mathrm{~d} \\
028367\end{array}$ & 1.98 & $\begin{array}{l}8.87 \mathrm{E}- \\
175\end{array}$ & $\begin{array}{c}\text { Probable inorganic } \\
\text { phosphate transporter 1-8 }\end{array}$ \\
\hline & $\begin{array}{c}\mathrm{Zm} 00001 \mathrm{~d} \\
031657\end{array}$ & 2.5005 & $\begin{array}{l}1.06 \mathrm{E}- \\
135\end{array}$ & $\begin{array}{l}\text { Inorganic phosphate } \\
\text { transporter 1-6 }\end{array}$ \\
\hline & $\begin{array}{c}\mathrm{Zm} 00001 \mathrm{~d} \\
0348 \underline{39}\end{array}$ & 2.7742 & $\begin{array}{c}1.39 \mathrm{E}- \\
10\end{array}$ & $\begin{array}{l}\text { Inorganic phosphate } \\
\text { transporter 1-11 }\end{array}$ \\
\hline \multirow{3}{*}{$\begin{array}{l}\mathrm{N} \text { vs } \\
\mathrm{NP}\end{array}$} & $\begin{array}{c}\mathrm{Zm} 00001 \mathrm{~d} \\
028367\end{array}$ & 1.6638 & $\begin{array}{l}4.33 \mathrm{E}- \\
23\end{array}$ & Purple acid phosphatase 3 \\
\hline & $\begin{array}{l}\mathrm{Zm} 00001 \mathrm{~d} \\
029038\end{array}$ & 1.9249 & $\begin{array}{l}2.16 \mathrm{E}- \\
26\end{array}$ & Acid phosphatase 1 \\
\hline & $\begin{array}{c}\mathrm{Zm00001d} \\
031875\end{array}$ & 1.7468 & $\begin{array}{c}4.43 \mathrm{E}- \\
71\end{array}$ & $\begin{array}{l}\text { Inorganic phosphate } \\
\text { transporter 1-6 }\end{array}$ \\
\hline
\end{tabular}

\subsection{Key DEGs related to $\mathrm{K}+$ transporters activity between $\mathbf{N}$ group, $\mathbf{P}$ group and NP group}

There were 5 DEGs related to $\mathrm{K}^{+}$transporters activity in $\mathrm{N}$ group versus $\mathrm{P}$ group and no $\mathrm{DEG}$ related to $\mathrm{K}^{+}$ transporters activity in $\mathrm{N}$ versus NP group (Table 3 ). The three of them in $\mathrm{N}$ group versus $\mathrm{P}$ group were downregulated, and the remaining two showed up-regulated. In genes that were significantly up-regulated, Zm00001d011473 (potassium channel AKT1) showed the most significant expression differences.

Table 3 Differentially expressed transporters involved in potassium metabolism of QXH0121 identified in $\mathrm{N}$ group versus $\mathrm{P}$ group and $\mathrm{N}$ group versus $\mathrm{NP}$ group by transcriptomic analysis $\left(\mid \log _{2}\right.$ FoldChange $\mid>1.5$, and Pval $\left.<0.05\right)$.

\begin{tabular}{|c|c|c|c|c|}
\hline $\begin{array}{l}\text { Treat- } \\
\text { ment }\end{array}$ & Gene_ID & $\begin{array}{l}\log _{2} \text { Fold } \\
\text { Change }\end{array}$ & Pval & SwissProt \\
\hline \multirow{4}{*}{$\mathrm{N}$ vs $\mathrm{P}$} & $\begin{array}{c}\mathrm{Zm00001d} \\
011473\end{array}$ & 2.197 & $5.24 \mathrm{E}-105$ & $\begin{array}{l}\text { Pota } \\
\text { chann }\end{array}$ \\
\hline & $\begin{array}{c}\mathrm{Zm} 00001 \mathrm{~d} \\
003555\end{array}$ & 1.8728 & $1.38 \mathrm{E}-23$ & $\begin{array}{c}\text { Potassium } \\
\text { channel KOR2 }\end{array}$ \\
\hline & $\begin{array}{c}\mathrm{Zm} 00001 \mathrm{~d} \\
044056\end{array}$ & -1.5595 & 4.78E-121 & $\begin{array}{c}\text { Potassium } \\
\text { channel AKT1 }\end{array}$ \\
\hline & $\begin{array}{c}\mathrm{Zm} 00001 \mathrm{~d} \\
042244\end{array}$ & -1.7341 & $7.08 \mathrm{E}-78$ & $\begin{array}{l}\text { Potassium } \\
\text { transporter } 5\end{array}$ \\
\hline
\end{tabular}




\begin{tabular}{cccc}
$\begin{array}{c}\text { Zm00001d } \\
033071\end{array}$ & -1.7681 & $8.14 \mathrm{E}-39$ & $\begin{array}{c}\text { Potassium } \\
\text { transporter } 21\end{array}$ \\
\hline
\end{tabular}

\subsection{The $q R T-P C R$ analysis}

The 10 DEGs involved in nitrogen metabolism, Pi transporters and $\mathrm{K}^{+}$transporters were chosen to verify the RNA-seq gene expression analysis. The result showed that except 2 genes (Zm00001d033071, no significant difference; Zm00001d026221, reverse), the others showed same regulation mode, which confirmed the reality of RNA-seq data (Fig. 8).
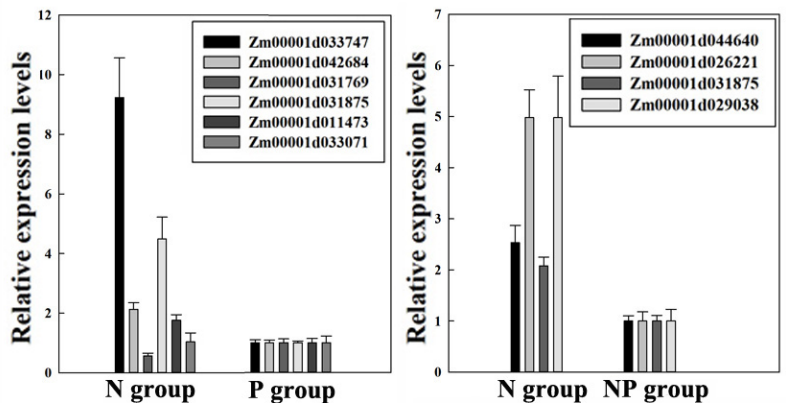

Fig. 8 Relative expression level of 10 DEGs in maize identified in $\mathrm{N}$ group versus $\mathrm{P}$ group and $\mathrm{N}$ group versus NP group RNAseq analysis from qRT-PCR. Data are average of 5 replicates \pm $\mathrm{SD}$, and different letters indicate significant difference at $\mathrm{P} \leq$ 0.05 .

\section{Discussions}

Plant growth was closely related to nutrient availability. Previous studies showed that plants could change root morphology architecture to respond to single nitrogen or phosphorus starvation $[25,26]$. Generally, nitrogen and phosphorus deficiencies lead to the inhibition of shoot and root growth [27, 28]. The primary root length of plants under nitrogen and phosphorus starvation usually decreased and root/shoot ratio increased [29-31]. Maize is no exception to this nutrient deficiency phenotype. The growth of maize was also strongly associated with nutrient. Our result showed that under nitrogen and phosphorus starvation, maize growth was severely inhibited. Plant height, primary root length, total root surface area and root volume decreased markedly. Biomass also decreased obviously and shoot root ratio increased significantly. These results verified that nitrogen and phosphorus played crucial role in maize growth and development such as it has been described in Arabidopsis and Eustoma plant species[32, 33].

Though phosphorus was indispensable, compared with phosphorus, nitrogen played much more important role in restoring plant growth when undergone low nitrogen and phosphorus dual stress as it has been widely studied in other plant species $[34,35]$. In our result, though co-application of nitrogen and phosphorus showed the most significant relief, apart from fresh weight, there was no significant difference between the plant height, root length, root/shoot ratio and dry weight of $\mathrm{N}$ group and NP group. So in view of the need for efficient and sustainable development, application of nitrogen alone or mainly nitrogen and supplementing with less phosphorus fertilizers can significantly alleviate stress damage caused by low nitrogen and phosphorus deficiency. Therefore, considering the need of efficient, economical and sustainable development, only appropriate amount of nitrogen or nitrogen plus a small amount of phosphorus can ensure the normal growth of maize.

Nitrogen and phosphorus played different but interrelated roles in plants [36-38]. Recent studies showed that in Arabidopsis thaliana, HRS1, a NRT1.1/CHL1 NLP7 dependent transcription factor, represses the primary root growth in response to low $\mathrm{P}$ condition when $\mathrm{PO}_{4}{ }^{3-}$ is absent and $\mathrm{NO}_{3}{ }^{-}$is present [39]. NPF7.3/NRT1.5, as a low affinity $\mathrm{NO}_{3}{ }^{-}$transporter was intensely induced by phosphorus starvation and the mutation of AtNRT1.5 enhanced the expression of phosphorus starvationinduced genes under phosphorus starvation [40]. Applying nitrogen fertilizer to Hybrid Middle Rice can increase the absorption and accumulation of nitrogen and certain phosphorus [41]. In our result, nitrogen application could promote the accumulation of phosphorus and nitrogen, but phosphorus application had no significant effect on nitrogen accumulation which indicated that the presence of nitrogen may be necessary for the absorption of phosphorus. However, the presence of phosphorus had no significant effect on nitrogen absorption. These all indicated that there was a certain correlation between nitrogen and phosphorus metabolism in maize, and phosphorus metabolism processes may work better in the presence of nitrogen.

Analysis of transcriptome data showed that there were significantly more DEGs in $\mathrm{N}$ versus $\mathrm{P}$ group than in $\mathrm{N}$ versus $\mathrm{NP}$ group. And all of the differentially expressed Pi transporters were up-regulated in either the $\mathrm{N}$ group vs $\mathrm{P}$ group or the $\mathrm{N}$ group vs NP group. This adequately indicated that the present of nitrogen may promote the expression of phosphorus transporters. Most of the nitrogen metabolism involved genes were downregulated. These results indicated that the presence of nitrogen may proceed or induce the expression of $\mathrm{Pi}$ related genes. These inferences need more detailed and in-depth research, so next we will deeply explore the interaction between genes involved in the absorption and transport of nitrogen and phosphorus in maize plants.

\section{Acknowledgements}

The work was supported by Shandong Provincial Major Scientific and Technological Innovation Project (2019JZZY020603), Shandong Provincial "Bohai Granary" Science and Technology Demonstration Project (2019BHLC003), Shandong Provincial Agricultural Major Applied Technology Innovation Project (SD2019ZZ013) and Natural Science Foundation of Shandong Province (ZR2020QC105).

\section{Authors' contributions}

Bingying Leng and Hanhan Zhang contributed equally to this work. Xia Liu, Enying Zhang and Bingying Leng 
designed the experiment. Bingying Leng, Hanhan Zhang, Chunhua $\mathrm{Mu}$, Xia Liu performed the experiment. Bingying Leng, Hanhan Zhang and Xia Liu finished the manuscript. Chunhua $\mathrm{Mu}$ and Enying Zhang provided materials. All authors checked and approved the final manuscript.

Table S1 Primer sequence of qRT-PCR genes in N versus $\mathrm{P}$ group and $\mathrm{N}$ versus NP group.

\begin{tabular}{cccc}
\hline Treat & Gene ID & Sense primer (5'-3') & Anti primer (5'-3') \\
& & & \\
\hline & Zm00001 & CATTCTTGAGAG & TGGTGCTGTAGT \\
& d033747 & GATCACCGAG & TGGTGTG \\
& Zm00001 & CACGTATACTGA & CACGCCTTTCAC \\
& d042684 & ATCGAGCCC & TTCTTCAC \\
& Zm00001 & ACTACCATTACA & TCACCGAGTTTA \\
& d031769 & AGGACAACCG & TGTTCAGCTC \\
$\mathrm{N}$ & Zm00001 & GTACCACTTCACC & GCTTAGTCACGA \\
versus & d031875 & GCCATC & GGGAGATG \\
$\mathrm{P}$ & Zm00001 & TTTTGAAGCGTG & CCTTCGGAGTCT \\
& $\mathrm{d} 011473$ & GTTTGGATC & CTAGCATTTG \\
& Zm00001 & TTCAACCCCAAG & AGTATCCCAGAT \\
----- & d033071 & TACATCGTC & TCGCAAAGAG \\
\hline & Zm00001 & AGTCAATTGCTCC & CTAGAAAGGGC \\
& d044640 & AGTAGGTG & TCAAAGGTGG \\
& Zm00001 & GTGCCACTCATTC & AGGACGGTCTCT \\
$\mathrm{N}$ & $\mathrm{d} 026221$ & AGAACAAG & AGGTACAC \\
versus & Zm00001 & GTACCACTTCACC & GCTTAGTCACGA \\
$\mathrm{NP}$ & $\mathrm{d} 031875$ & GCCATC & GGGAGATG \\
& Zm00001 & CCTCTCCAACCTG & GACCTTGAAGCC \\
& d029038 & CTCTACT & CTTGTCC \\
\hline
\end{tabular}

\section{References}

1. Z.A. Huang, D.A. Jiang, Y. Yang, J.W. Sun, S.H. Jin. Effects of nitrogen deficiency on gas exchange, chlorophyll fluorescence, and antioxidant enzymes in leaves of rice plants, Photosynthetica 42, 357-364 (2004)

2. S.M. Jeon, K.H. Ka. Nitrogen source-requirement and preference of ectomycorrhizal fungi in pure culture, The Korean J. Mycol 41, 149-159 (2013)

3. U. Schlüter, M. Mascher, C. Colmsee, U. Scholz, A. Bräutigam, H. Fahnenstich, U. Sonnewald. Maize source leaf adaptation to nitrogen deficiency affects not only nitrogen and carbon metabolism but also control of phosphate homeostasis, Plant Physiol 160, 1384-1406 (2012)

4. S. Abel, C.A. Ticconi, C.A. Delatorre. Phosphate sensing in higher plants, Physiol. Plantarum 115, 1-8 (2002)

5. A.E. Richardson, J.P. Lynch, P.R. Ryan, E. Delhaize, F.A. Smith, S.E. Smith, P.R. Harvey, M.H. Ryan, E.J. Veneklaas, H. Lambers. Plant and microbial strategies to improve the phosphorus efficiency of agriculture, Plant Soil 349, 121-156 (2011)

6. C.P. Vance, C. Uhde-Stone, D.L. Allan. Phosphorus acquisition and use: critical adaptations by plants for securing a nonrenewable resource, New Phytol 157, 423-447 (2010)
7. K. Kitayama, S.I. Aiba, M. Takyu, N. Majalap, R. Wagai. Soil phosphorus fractionation and phosphorus-use efficiency of a bornean tropical montane rain forest during soil aging with podozolization, Ecosystems 7, 259-274 (2004)

8. T. Kiba, A.B. Feria-Bourrellier, F. Lafouge, L. Lezhneva, S. Boutet-Mercey, M. Orsel, V. Bréhaut, A. Miller, F. Daniel-Vedele, H. Sakakibara. The Arabidopsis nitrate transporter NRT2. 4 plays a double role in roots and shoots of nitrogen-starved plants, Plant Cell 24, 245-258 (2012)

9. D. Cordell, J.O. Drangert, S. White. The story of phosphorus: global food security and food for thought, Global Environ. Chang 19, 292-305 (2009)

10. J. Shen, L. Yuan, J. Zhang, H. Li, Z. Bai, X. Chen, W. Zhang, F. Zhang. Phosphorus dynamics: from soil to plant, Plant Physiol 156, 997-1005 (2011)

11. M. Wissuwa. How do plants achieve tolerance to phosphorus deficiency? Small causes with big effects, Plant Physiol 133, 1947-1958 (2003)

12. M. Wissuwa, N. Ae. Genotypic variation for tolerance to phosphorus deficiency in rice and the potential for its exploitation in rice improvement, Plant Breeding 120, 43-48 (2001)

13. K. Yoneyama, X. Xie, D. Kusumoto, H. Sekimoto, Y Sugimoto, Y. Takeuchi, K. Yoneyama. Nitrogen deficiency as well as phosphorus deficiency in sorghum promotes the production and exudation of 5-deoxystrigol, the host recognition signal for arbuscular mycorrhizal fungi and root parasites, Planta 227, 125-132 (2007)

14. S. Sen, M.E. Smith, T. Setter. Effects of low nitrogen on chlorophyll content and dry matter accumulation in maiz, Afr. J. Agr. Res. 11, 10011007 (2016)

15. Z. Liu, F. Gao, Y. Liu, J. Yang, X. Zhen, X. Li, Y. Li, J. Zhao, J. Li, B. Qian. Timing and splitting of nitrogen fertilizer supply to increase crop yield and efficiency of nitrogen utilization in a wheat-peanut relay intercropping system in China, Crop J 7, 101112 (2019)

16. C. Grant, S. Bittman, M. Montreal, C. Plenchette, C. Morel. Soil and fertilizer phosphorus: Effects on plant P supply and mycorrhizal development, Can. J. Plant Sci 85, 3-14 (2005)

17. Y. Maeda, M. Konishi, T. Kiba, Y. Sakuraba, N. Sawaki, T. Kurai, Y. Ueda, H. Sakakibara, S. Yanagisawa. A NIGT1-centred transcriptional cascade regulates nitrate signalling and incorporates phosphorus starvation signals in Arabidopsis, Nat. Commun 9, 1376 (2018)

18. A. Medici, W. Szponarski, P. Dangeville, A. Safi, I.M. Dissanayake, C. Saenchai, A. Emanuel, V. Rubio, B. Lacombe, S. Ruffel. Identification of molecular integrators shows that nitrogen actively controls the phosphate starvation response in plants, Plant Cell 31, 1171-1184 (2019) 
19. W.Y. Lin, T.K. Huang, T.J. Chiou. Nitrogen limitation adaptation, a target of microRNA827, mediates degradation of plasma membrane-localized phosphate transporters to maintain phosphate homeostasis in Arabidopsis, Plant Cell 25, 40614074 (2013)

20. B. Hu, Z. Jiang, W. Wang, Y. Qiu, Z. Zhang, Y. Liu, A. Li, X. Gao, L. Liu, Y. Qian. Nitrate-NRT1.1BSPX4 cascade integrates nitrogen and phosphorus signalling networks in plants, Nat. Plants 5, 401 (2019)

21. S. Kant, M. Peng, S.J. Rothstein. Genetic regulation by NLA and microRNA827 for maintaining nitratedependent phosphate homeostasis in Arabidopsis, PLoS Genet 7, e1002021 (2011)

22. C. Calderón-Vázquez, R.J. Sawers, L. Herrera Estrella. Phosphate deprivation in maize: genetics and genomics, Plant Physiol 156, 1067-1077 (2011)

23. Y. Sun, C. Mu, Y. Chen, X. Kong, Y. Xu, H. Zheng, H. Zhang, Q. Wang, Y. Xue, Z. Li. Comparative transcript profiling of maize inbreds in response to long-term phosphorus deficiency stress, Plant Physiol. Bioch 109, 467-481 (2016)

24. Y. Sun, C. Mu, H. Zheng, S. Lu, H. Zhang, X. Zhang, X. Liu. Exogenous Pi supplementation improved the salt tolerance of maize (Zea mays L.) by promoting $\mathrm{Na}^{+}$exclusion, Sci. Rep 8, 16203 (2018)

25. J. López-Bucio, A. Cruz-Ramırez, L. HerreraEstrella. The role of nutrient availability in regulating root architecture, Curr. Opin. Plant Biol 6, 280-287 (2003)

26. B.D. Gruber, R.F. Giehl, S. Friedel, N. von Wirén. Plasticity of the Arabidopsis root system under nutrient deficiencies, Plant Physiol 163, 161-179 (2013)

27. R. Shin, R.H. Berg, D.P. Schachtman. Reactive oxygen species and root hairs in Arabidopsis root response to nitrogen, phosphorus and potassium deficiency, Plant Cell Physiol 46, 1350-1357 (2005)

28. S. Osborne, J.S. Schepers, D. Francis, M.R. Schlemmer. Detection of phosphorus and nitrogen deficiencies in corn using spectral radiance measurements, Agron. J 94, 1215-1221 (2002)

29. J.P. Lynch, K.M. Brown, Root strategies for phosphorus acquisition, in: The ecophysiology of plant-phosphorus interactions, Springer Netherlands, 2008, pp. 83-116.

30. Y.F. Niu, R.S. Chai, G.L. Jin, H. Wang, C.X. Tang, Y.S. Zhang. Responses of root architecture development to low phosphorus availability: a review, Ann. Bot-LONDON 112, 391-408 (2012)

31. H. Sun, J. Tao, S. Liu, S. Huang, S. Chen, X. Xie, K. Yoneyama, Y. Zhang, G. Xu. Strigolactones are involved in phosphate-and nitrate-deficiencyinduced root development and auxin transport in rice, J. Exp. Bot 65, 6735-6746 (2014)

32. C.T. Chen, C.L. Lee, D.M. Yeh. Effects of nitrogen, phosphorus, potassium, calcium, or magnesium deficiency on growth and photosynthesis of Eustoma, HortSci 53, 795-798 (2018)

33. T. Araya, T. Kubo, N. von Wirén, H. Takahashi. Statistical modeling of nitrogen-dependent modulation of root system architecture in Arabidopsis thaliana, J. Integr. Plant Biol. 58, 254265 (2016)

34. M.A. Begum, M.A. Islam, Q.M. Ahmed, M.A. Islam, M.M. Rahman. Effect of nitrogen and phosphorus on the growth and yield performance of soybean, Agroaid Found 2, 35 (2015)

35. H.A. Eltelib, M.A. Hamad, E.E. Ali. The effect of nitrogen and phosphorus fertilization on growth, yield and quality of forage maize (Zea mays L.), J. Agron 5, 515-518 (2006)

36. L.C. Carvalhais, P.G. Dennis, D. Fedoseyenko, M.R. Hajirezaei, R. Borriss, N. von Wirén. Root exudation of sugars, amino acids, and organic acids by maize as affected by nitrogen, phosphorus, potassium, and iron deficiency, J. Plant Nutr. Soil Sci 174, 3-11 (2011)

37. P.M. Vitousek, S. Porder, B.Z. Houlton, O.A. Chadwick. Terrestrial phosphorus limitation: mechanisms, implications, and nitrogen-phosphorus interactions, Ecol. Appl 20, 5-15 (2010)

38. L. Xin, H.Y. Hu, G. Ke, Y.X. Sun. Effects of different nitrogen and phosphorus concentrations on the growth, nutrient uptake, and lipid accumulation of a freshwater microalga Scenedesmus sp, Bioresource Technol 101, 5494-5500 (2010)

39. A. Medici, A. Marshall-Colon, E. Ronzier, W. Szponarski, R. Wang, A. Gojon, N.M. Crawford, S. Ruffel, G.M. Coruzzi, G. Krouk. AtNIGT1/HRS1 integrates nitrate and phosphate signals at the Arabidopsis root tip, Nat. Commun 6, 6274 (2015)

40. Y.N. Cui, X.T. Li, J.Z. Yuan, F.Z. Wang, S.M. Wang, Q. Ma. Nitrate transporter NPF7. 3/NRT1. 5 plays an essential role in regulating phosphate deficiency responses in Arabidopsis, Biochem. Bioph. Res. Co 508, 314-319 (2019)

41. F.X. Xu, H. Xiong, L. Zhang, X.Y. Guo, Y.C. Zhu, X.B. Zhou, M. Liu. Effect of nitrogen application on accumulation and distribution of nitrogen, phosphorus, potassium and dry matter of mid-season hybrid rice in winter paddy field, J. Agr. Sci. Tech 14, 118-126 (2012) 